\title{
NIETZSCHE, A CONTESTAÇÃO DO REALISMO PLATÔNICO DA LINGUAGEM E A CONSTATAÇÃO DA COMUNICABILIDADE USUAL COMO SINAL DA GREGARIEDADE DISCURSIVA
}

\author{
Nietzsche, the rebuttal of platonic realism of language and the finding of usual \\ communcability as signal of discursive gregariousness
}

\section{Renato Nunes Bittencourt}

Resumo: O artigo aborda as críticas de Nietzsche ao realismo platônico da linguagem, cuja concepção pressupõe a existência de um substrato metafísico que concede significado verdadeiro para as palavras. A crítica nietzschiana aos paradigmas da linguagem usual também exige uma denúncia da sua impossibilidade em representar convenientemente a pluralidade de vivências, evidenciando o seu caráter excludente e negador das diferenças. Como saída para tal problema epistemológico e comunicacional, Nietzsche restaura o valor enunciativo do discurso artístico, cujo caráter metafórico supera as limitações semânticas da linguagem prosaica.

Palavras-Chave: Linguagem; Verdade; Comunicação; Expressão; Semântica.

Abstract: The article approaches the Nietzsche's critic to the platonic realism of the language, whose conception presupposes the existence of a metaphysical substrate which grants real meaning to the words. The nietzschean critic to the paradigms of the usual language also demands a complaint of its impossibility into represent conveniently the plurality of experiences, evidencing its exclusive character and denial of differences. As an exit to that epistemological and communicational problem, Nietzsche restores the enunciation value of artistic discourse, whose metaphorical character overcomes the limitations of semantic prosaic language

Keywords: Language; Truth; Communication; Expression; Semantics.

A "razão" na linguagem: Oh, que velha e enganadora senhora! Receio que não nos livraremos de Deus, pois ainda cremos na gramática... ${ }^{1}$

\section{Introdução}

A filosofia de Nietzsche se caracteriza por sua crítica radical aos valores fundamentais da civilização ocidental, enraizada em um projeto metafísico e moral que regulou normativamente as suas ações sociais e suas criações culturais. Contra o pensamento socrático-platônico, Nietzsche objetará a cisão entre razão e instinto e a

1 NIETZSCHE, Friedrich. Crepúsculo dos ídolos como se filosofa com o martelo. Trad. de Paulo César de Souza. São Paulo: Companhia das Letras, 2006., p. 28. 
promoção do homem teórico, que divorcia ação e pensamento; contra a moral religiosa cristã, o ressentimento contra a vitalidade exuberante condenada como pecaminosa e o estabelecimento de uma consciência culpada no âmago do rebanho de devotos.

Podemos afirmar que o embate de Nietzsche contra os grandes paradigmas fundamentais da civilização ocidental se caracteriza pela tentativa de se resgatar os valores trágicos da imanência e da contingência perante narrativas universalistas que pressupõem a existência de uma verdade plena e a capacidade humana de conhecê-la intrinsecamente, uma condição moral perfeita, um modelo de conduta a ser alcançada pelo ser humano e efetivada tanto a nível individual como social. Por conseguinte, a análise crítica sobre a questão da linguagem e da comunicação de modo algum poderia deixar de ser problematizada por Nietzsche, que apresentou continuamente ao longo de sua trajetória filosófica importantes contribuições para esses estudos, foco de nossa reflexão. No decorrer do texto, diversas obras do filósofo alemão serão analisadas, demonstrando que, apesar de representarem fases distintas do pensamento nietzschiano, existe, todavia, uma grande coerência na sua crítica aos fundamentos metafísicos do platonismo, cuja teoria da linguagem pautada no postulado de uma verdade transcendente se configurou como um grande paradigma epistemológico norteador do substrato idealista da filosofia e do discurso científico. Cabe então a sua desmistificação em prol da ratificação do pensamento da imanência. Em seguida realizaremos uma análise sobre as motivações nietzschianas de sua crítica ao discurso prosaico da comunicação social, incapacidade, não obstante todos os seus esforços enunciativos, em expressar convenientemente a intensidade das vivências humanas, demasiadamente singulares inefáveis.

\section{A crítica ao realismo platônico da linguagem}

Ao apresentar a objeção ao caráter epistemológico e moral embutido tradicionalmente no conceito de verdade, Nietzsche se contrapõe ao realismo platônico da linguagem, segundo o qual existe adequação plena entre os nomes e as coisas denominadas. A palavra representaria a essência dos entes, e o filósofo- 
legislador é o sujeito mais capacitado a decifrar o âmago das coisas e representá-las convenientemente com signos linguísticos.

A tarefa de pensarmos o problema epistemológico da comunicação através do enfoque nietzschiano envolve necessariamente uma reflexão sobre os processos da linguagem e de que maneira ela se constitui semanticamente na imanência da prática social. Nietzsche, configurando-se como um crítico radical da teoria platônica da linguagem, explicitada especialmente no Crátilo, considerará que não existe a postulada justeza entre as coisas e as suas respectivas denominações, noção que sustenta a metafísica da linguagem idealizada por Platão na citada obra. Dessa maneira, a perspectiva realista da linguagem, que encontra na filosofia platônica os seus elementos originários, se caracteriza por defender a tese que as palavras e os conceitos constituintes de um sistema linguístico representam entidades absolutas, abstratas, independentes da mente humana e da própria concretude mundana.

O mote do Crátilo consiste na apresentação da proposta platônica de investigar se porventura existe um nexo ontológico e lógico entre o objeto e a sua denominação, a partir da adequação intrínseca dos nomes em relação às coisas. ${ }^{2}$ Hermógenes, personagem representado no diálogo platônico como defensor de um viés convencionalista para a formação da linguagem e dos seus aparatos comunicativos, defende a inexistência de um vínculo natural entre o objeto e a sua denominação, considerando que essa relação seria arbitrária, de modo que o nome do objeto decorreria diretamente da escolha daquele que detém o poder de intitular as coisas existentes, isto é, o legislador. Conforme o discurso de Hermógenes, nenhum nome é dado por natureza a qualquer coisa, mas pela lei e o costume dos que se habituaram a chamá-la dessa maneira. ${ }^{3}$ Com efeito, percebemos uma surpreendente aproximação axiológica dessa perspectiva com aquela apresentada por Nietzsche no $\S 2$ da primeira dissertação da Genealogia da Moral, passagem na qual o filósofo alemão defende a tese de que são os homens proeminentes no processo de formação organizacional de uma sociedade, "os senhores", que portavam o direito de nomear as coisas, como que, apontando para elas, dissessem: "isto é isto", marcando assim cada coisa e/ou

\footnotetext{
2 PLATÃO, Crátilo. Trad. de Maria José Figueiredo. Lisboa: Instituto Piaget, 2001, 383a.

${ }^{3}$ Idem, 384d.
} 
acontecimento com um determinado som, como que se apropriando simbolicamente da representação dessas coisas. Nessas condições, cada situação recebe tanto o estatuto de designado quanto um nome especifico, cuja procedência, em ambos os casos, remete imediatamente à ação "senhoril" de designação para as coisas.

O interlocutor Crátilo, por sua vez, defende a tese de que os nomes das coisas derivam imediatamente de sua natureza abstrata e que nem todo homem pode ser um formador de nomes, mas apenas aquele que, contemplando a natureza de cada coisa, desvela o nome que cada coisa tem por natureza, sabe como exprimir com letras e sílabas a sua idéia fundamental. ${ }^{4}$ Trata-se de um projeto racionalista que nega o valor da sensibilidade e suas complexas relações concretas. Nietzsche designa esse projeto de metafísica da linguagem:

A linguagem pertence, por sua origem, à época da mais rudimentar forma de psicologia: penetramos um âmbito de cru fetichismo, ao trazermos à consciência os pressupostos básicos da metafísica da linguagem, isto é, da razão. É por isso que em toda parte vê agentes e atos: acredita na verdade como causa; acredita no "eu", no Eu como ser, no Eu como substância, e projeta a crença no eu-substância em todas as coisas - apenas então cria o conceito de coisa. ${ }^{5}$

Partindo de uma orientação axiológica contrária, Nietzsche defende a tese de que as designações concedidas para as coisas nascem de um mecanismo arbitrário de concessão de nomes, e esse processo é movido por interesses políticos e sociais regidos por critérios rigorosamente extra-morais, imanentes ao âmbito das urgências da vida cotidiana. Por conseguinte, qualquer tipo de denominação, quando elaborada pelo homem como forma de representar semanticamente alguma coisa, não mantém qualquer tipo de vínculo ontológico com a sua "essência", cuja noção, na concepção nietzschiana, é uma mera ilusão gerada pela racionalidade humana, em sua pretensão de encontrar termos gerais, comuns, entre os objetos do mundo, vislumbrando assim alcançar uma esperada verdade transcendente e possíveis compartilhamentos de experiências em suas vivências cotidianas. De acordo com Éric Blondel, "Nietzsche

\footnotetext{
${ }^{4}$ Idem, 390e.

${ }^{5}$ NIETZSCHE, Crepúsculo dos Ídolos ou como se filosofa com o martelo, p. 28.
} 
etimologista chega a conclusões radicalmente opostas às de Crátilo. Segundo ele, a etimologia não prova a naturalidade da linguagem, mas, ao contrário, sua convencionalidade, seu caráter arbitrário, sua falsidade". ${ }^{6}$ Já Fernando Belo agrega conteúdo a tal problematização ao afirmar que "arbitrária, a designação diz respeito apenas às relações coisas/homem; a formação da língua joga ao nível do arbitrário". ${ }^{7}$

Esse processo de denominação para os objetos, portanto, não descreve a totalidade de qualidades específicas que se encontram presentes nos mesmos, sendo então uma redução semântica de toda possibilidade discursiva. A linguagem de signos, que reúne todas as leis observadas, não explica efetivamente nada, pois é somente uma maneira de descrever o mais resumidamente possível um acontecimento; o seu substrato semântico, compreendido por um viés imanente, não é o de substituir a presença física dessa coisa pela designação abstrata, mas sim de conceder uma significação (parcial) entre muitas outras possíveis. A palavra, além de não se associar intrinsecamente ao objeto designado, tampouco é capaz de representar ou descrever adequadamente a sua "essência", que, por sua vez, também é uma fabulação de cunho metafísico nascida de uma necessidade humana de se acreditar em realidades imutáveis, e assim adquirir uma espécie de "conforto moral" diante da efemeridade do mundo e da própria vida. Nietzsche postula que

A essência plena das coisas nunca é apreendida. As nossas expressões verbais nunca esperam que a nossa percepção e nossa experiência nos tenham fornecido sobre a coisa um conhecimento exaustivo e, de algum modo, respeitável. ${ }^{8}$

Ora, se o sistema da linguagem não expressa jamais qualquer teor de veracidade situada para além da esfera da imanência, a única existente, a comunicação humana, nascida justamente através das interações lingüísticas, será incapaz de representar qualquer parâmetro axiológico imputado como transcendente ou ainda expressar de forma nítida e adequada as suas mais particulares vivências individuais. "A linguagem é retórica porque apenas quer transmitir uma doxa, e não uma

\footnotetext{
${ }^{6}$ BLONDEL, Éric. "As Aspas de Nietzsche: Filologia e Genealogia" In: MARTON, Scarlett (org.) Nietzsche Hoje? Trad. de Milton Nascimento. São Paulo: Brasiliense, 1985, p. 115.

${ }^{7}$ BELO, Fernando. Leituras de Aristóteles e de Nietzsche. Lisboa: Calouste Gulbenkian, 1994, p. 224.

${ }^{8}$ NIETZSCHE, Friedrich. Da Retórica. Trad. de Tito Cunha. Lisboa: Vega, 1999.p. 45.
} 
episteme", tal como assinala Nietzsche. ${ }^{9}$ Por conseguinte, as qualidades retóricas da linguagem atrelam-se apenas ao plano concreto das relações sociais, impedindo uma compreensão global da realidade, apesar das pretensões metafísicas de se alcançar a verdade através do discurso; para tanto, seria imprescindível a existência de um sistema linguístico perfeito, mas tal hipótese é gnosiologicamente irrealizável, pois a linguagem surge de maneira rudimentar na esfera social, sofrendo aprimoramentos em sua estrutura semântica no decorrer das eras sem que, todavia, se favoreça o enriquecimento das interações comunicativas entre os indivíduos. Analisando essa problemática nietzschiana, Eugen Fink afirma que "o homem crê em coisas, mas não existe nenhuma coisa; crê no 'ente', mas este ente é sua própria criação, essa trama conceitual continuamente lançada nas ondas do vir-a-ser". ${ }^{10}$

O projeto comunicacional se fundamenta, portanto, em bases morais que mascaram suas contradições epistemológicas, pois a necessidade humana de conhecer a verdade e representá-la discursivamente se converteu historicamente em mandamento normativo regulador das relações sociais, estigmatizando toda expressão discursiva alheada dos pretensos critérios de verdade, inclusive através de ações concretas de anulação e eliminação daqueles que não compactuam com os valores normativos dominantes. Quem não compactua da verdade dogmática da religião imputada como a única, quem não aceita a autoridade onipotente do Deus imputado como o único, corre o risco de ser eliminado.

\section{A constatação e a contestação da natural incapacidade semântica da linguagem}

A imprecisão descritiva das palavras em relação aos objetos originais e o caráter de arbitrariedade da estrutura da linguagem desenvolvida pelo homem conduzem a denominações semânticas nitidamente insuficientes, que de modo algum podem apreender a totalidade das qualidades e dos aspectos singulares dos objetos enunciados; mais ainda, podemos até mesmo colocar em xeque a tese de que se de fato existe essa pretensa realidade essencial considerada como o substrato de todas as

\footnotetext{
${ }^{9}$ Idem, p. 46.

10 FINK, EUGEN, "Nova experiência de mundo em Nietzsche". In: MARTON, Scarlett (org.) Nietzsche Hoje? Trad. de Sonia Salzstein Goldberg. São Paulo: Brasiliense, 1985, p. 178.
} 
coisas, que a concepção metafísica da linguagem postula compreender mediante a descrição rigorosa dos atributos de uma dada coisa, como se ela conhecesse a sua "essência". Tal perspectiva, no entanto, desconhece a atividade subjetiva nos atos de enunciação acerca de algo, processo motivado por circunstâncias puramente particulares e contingentes. Aplicando-se essa concepção crítica do sistema da linguagem nas práticas comunicativas, dissolve-se qualquer pretensão de se alcançar uma noção de veracidade imutável, metafísica, tampouco de se falar sobre a "verdade", pois como um instrumento comunicativo, intrinsecamente falho e limitador das possibilidades interpretativas, podem tratar de um conceito que é postulado como "preciso", "evidente" e "objetivo"?

A pretensão platônica de o processo enunciativo conseguir tratar da "verdade" autêntica se revela um engodo, pois a dita "verdade" é apenas uma perspectiva singular, intrinsecamente limitada, e o próprio discurso que dela se apropria não dá conta de representar adequadamente a dinâmica criativa da realidade. Uma vez que não existe qualquer adequação ontológica entre as palavras e as coisas, o postulado de se alcançar a "verdade em si" através do discurso se torna uma quimera gnosiológica; mais precisamente, sequer existe essa "verdade em si", mas apenas um jogo fluido de superfícies. Todavia, a comunidade projeta para uma pretensa realidade superior a presença de uma dimensão inteligível na qual existe uma veracidade plena que sustenta todo conhecimento humano. Nietzsche indaga:

O que é, pois, a verdade? Um exército móvel multiplicidade de metáforas, metonímias, antropomorfismos, numa palavra, uma soma de relações humanas que foram realçadas poética e retoricamente, transpostas e adornadas, e que, após uma longa utilização, parecem a um povo consolidadas, canônicas e obrigatórias: as verdades são ilusões das quais se esquece que elas assim o são, metáforas que se tornaram desgastadas e sem força sensível, moedas que perderam seu toque e agora são levadas em conta apenas como metal, e não mais como moedas. $^{11}$

${ }^{11}$ NIETZSCHE, Friedrich. Sobre verdade e mentira no sentido extra-moral, Trad. de Fernando de Moraes Barros. São Paulo: Hedra, 2007, p.36-37. 
Nesses termos, a noção de "verdade", construída socialmente a partir da vida prática da comunidade de falantes, perde a sua configuração primordial, isto é, a de ser uma valoração "falsa" da realidade para que se permita o estabelecimento da comunicação entre as pessoas. O decorrer do tempo jogou ao esquecimento a noção de que a aplicação do conceito de verdade e a expressão descritiva da linguagem surgem como instâncias criativas do intelecto humano em suas vivências imanentes, e não por uma racionalidade abstrata fundamentada em uma instância metafísica que nega justamente o caráter singular da existência. Para Rosana Suarez,

O que Nietzsche põe em dúvida desde o inicio é a experiência de um mundo substancial ao qual pudéssemos ligar a linguagem numa relação explicativa, causal. Ao contrário, tal mundo "substancial" nasceria como um efeito, como uma ilusão da linguagem. Neste sentido, o conceito seria a palavra mais mentirosa. Ao buscar um denominador comum para as coisas, a fim de instaurar uma linguagem homogênea, universalmente válida, o conceito encontraria o vácuo, o interstício de todas as marcas contingentes, parciais, com as quais assinalamos o mundo desde que 0 percebemos. ${ }^{12}$

Evidencia-se assim que a interação comunicativa humana é sempre uma experiência semiologicamente redutora, tornando-se tecnicamente impossível a ocorrência de qualquer entendimento preciso entre os falantes, mas apenas o estabelecimento de analogias de vivências, consideradas comuns por esse processo de reducionismo semântico, e não por uma similitude natural. Conforme argumenta Pierre Klossowski acerca dessa questão nietzschiana,

(...) a linguagem é o simulacro da singularidade obstinada de nossa busca pela verdade sem véus: pois se recorremos à linguagem é porque através da fixidez dos signos ela oferece também o equivalente da nossa singularidade obstinada; e se também podemos credenciar, pela linguagem, como "verdadeira" uma ideia "falsa" para nós mesmos, cuja única "verdade" é nossa repulsa de trocar nossos fantasmas por qualquer idéia institucional, é porque a fixidez

\footnotetext{
${ }^{12}$ SUAREZ, Rosana. Nietzsche e a linguagem. Rio de Janeiro: 7Letras, 2011, p. 106.
} 
dos signos simula, ao mesmo tempo, a resistência do meio institucional. ${ }^{13}$

A criação das palavras decorre de um anseio de se permitir efetivamente a designação dos objetos através do uso da convenção entre os homens, os quais, ao se depararem com a surpreendente realidade, se viram diante da necessidade de "etiquetar", "rotular" os objetos, através de palavras que porventura acreditavam ter algum tipo de vínculo ontológico com as coisas que se ansiava designar. De acordo com Leon Kossovitch, "a designação é uma operação simplificadora, pois a distância entre a palavra e a coisa é insuperável: a linguagem está sempre aquém do objeto, assim como a identidade é o esvaziamento da diferença". ${ }^{14} \mathrm{~A}$ palavra, ao nascer de um projeto de identificação ontológica acerca de um ente em constante devir, o petrifica, tornando-se artificialmente apreensível para a mentalidade comum que somente consegue se relacionar com substâncias, formas e estruturas pretensamente fixas. Prosseguindo em seu empreendimento de desmistificação do processo de formação da linguagem, Nietzsche salienta que

Dispostas lado a lado, as diferentes línguas mostram que, nas palavras, o que conta nunca é a verdade, jamais uma expressão adequada: pois, do contrário, não haveria tantas línguas. A "coisaem-si" (ela seria precisamente a pura verdade sem quaisquer conseqüências) também é, para o criador da linguagem, algo totalmente inapreensível e pelo qual nem de longe vale a pena esforçar-se. Ele designa apenas as relações das coisas com os homens e, para expressá-las, serve-se da ajuda das outras metáforas. ${ }^{15}$

Todo discurso representa intrinsecamente uma redução de vivências. Para que haja qualquer ato comunicativo entre os indivíduos, as diversas experiências singulares são excluídas desse processo interativo, tendo-se em vista a possibilidade de compreensão interpessoal. Desse modo, o processo de elocução da linguagem, ao

\footnotetext{
${ }^{13}$ KLOSSOWSKI, Pierre. Nietzsche e o círculo vicioso. Trad. Hortênsia S. Lencastre. Rio de Janeiro: Pazulin, 2000, p. 286.

${ }^{14}$ KOSSOVITCH, Leon. Signos e poderes em Nietzsche. São Paulo: Azougue Editorial, 2004, p. 86.

15 NIETZSCHE, Friedrich. Sobre Verdade e Mentira no sentido extra-moral, p. 31-32. Comentando essa idéia nietzschiana, Fernando Belo salienta que "A existência de línguas diferentes mostra suficientemente que não se chega nem à verdade nem à expressão adequada das coisas através das palavras" (op. cit, p. 223).
} 
invés de promover o enriquecimento semântico da experiência vital, exerce um efeito empobrecedor de signos, gerando uma ruptura entre a pluralidade de vivências pessoais experimentadas no cotidiano e a capacidade de se pronunciar de maneira conveniente sobre as mesmas. Segundo Wolfgang Müller-Lauter,

O conceito não dá conta da verdade efetivamente existente de dois modos: em primeiro lugar, na medida em que fixa, quando de fato se processa o acontecer sem cessar; em segundo lugar, na medida em que subsume "casos claramente desiguais" como iguais. ${ }^{16}$

Qualquer ato de elocução nunca expressa adequadamente a riqueza existencial presente no impulso, sentimento ou na vivência singular que deram origem ao delineamento desse discurso, e tal impossibilidade certamente gera um mal-estar existencial no falante, impossibilitado de expressar plenamente para outrem as filigranas dos seus conteúdos comunicativos. Versando sobre o "homem gregário", criativamente e existencialmente limitado pela sedução ontológica proporcionada pela crença na metafísica da linguagem, Nietzsche destaca que

Ele abusa das convenções consolidadas por meio de trocas arbitrárias ou inversões dos nomes, inclusive. Se faz isso de uma maneira individualista e ainda por cima nociva, então a sociedade não confiará mais nele e, com isso, tratará de excluí-lo. Nisso, os homens não evitam tanto ser ludibriados quanto lesados pelo engano. Mesmo nesse nível, o que eles odeiam fundamentalmente não é o engano, mas as conseqüências ruins, hostis, de certos gêneros de enganos. Num sentido semelhantemente limitado, o homem também quer apenas a verdade. Ele quer as conseqüências agradáveis da verdade, que conservam a vida; frente ao puro conhecimento sem conseqüências ele é indiferente, frente às verdades possivelmente prejudiciais e destruidoras ele se indispõe com hostilidade, inclusive. E mais até: como ficam aquelas convenções da linguagem? São talvez produtos do conhecimento, do sentido da verdade: as designações e as coisas se recobrem? Então a linguagem é a expressão adequada a todas as realidades? Apenas por esquecimento pode o homem alguma vez chegar a imaginar que detém uma verdade no grau ora mencionado. ${ }^{17}$

16 MÜLLER-LAUTER, Wolfgang. Nietzsche: sua filosofia dos antagonismos e os antagonismos de sua filosofia. Trad. de Clademir Araldi. São Paulo: Ed. UNIFESP, 2009, p. 54.

${ }^{17}$ NIETZSCHE, Friedrich. Sobre Verdade e Mentira no sentido extra-moral, p. 29-30. 
É difícil expressarmos a originalidade de um pensamento mediante a linguagem ordinária, pois a comunicação exige a simplificação das vivências, uma vez que ela só pode transmitir o pretenso sentido das coisas através do discurso através de uma redução semântica ou abreviação das experiências, o que resulta numa dinâmica cognitiva completamente artificial que não corresponde ao âmbito efetivo das interações humanas. Inclusive, cabe neste momento que façamos uma reflexão sobre uma possível análise semântica do termo "comunicação": trata-se de tornar comum uma ação, comungar uma ação, partilha-la com outrem. Ora, aquilo que é comum desce ao âmbito do vulgar, do corriqueiro, ocasionando assim a supressão da possibilidade de uma afirmação da singularidade. Com efeito, seria possível uma comunicação daquilo que é raro, extraordinário, em suma, incomum? Conforme salienta Patrick Wotling,

A linguagem ordinária inevitavelmente deixa escapar a originalidade, mais ainda a independência, de um pensamento que pretende se elevar para além da experiência comum; ela "vulgariza" porque só pode exprimir por meio de uma redução, isto é, de uma simplificação: a traição ao pensamento aparece assim como condição mesma de seu trabalho de transmissão de sentido. ${ }^{18}$

O dispositivo social do processo de comunicação, no seu projeto de difundir informações para a coletividade, se utiliza de um modelo discursivo padronizado, no qual se pretende adequar a consciência da comunidade receptora diante de um conjunto de narrativas completamente estranhas aos seus critérios valorativos mais particulares, atuando como uma instância de caráter normativo, da qual se exige dos membros de uma comunidade a sua adesão integral. Para que algo seja comunicado, é necessário que se faça um recorte semântico na sua pluralidade de significações possíveis, gerando assim o malfadado empobrecimento axiológico de interpretações acerca da realidade circundante. Uma vez que o instrumento que possibilita a instauração da comunicação é a linguagem, esta, elaborada através de uma redução radical de sentidos e de valores, se torna a grande responsável pela degradação da

18 WOTLING, Patrick. Nietzsche e o problema da civilização. Trad. de Vinicius de Andrade. São Paulo: Barcarolla, 2013, p. 66-67. 
experiência da singularidade humana no seu âmbito societário. Para Oswaldo Giacóia Jr.,

A necessidade de comunicação, ligada à capacitação para tanto, não pode ser dimensionada em escala individual e particular; do ponto de vista de sua origem, essa necessidade de comunicação deve ser analisada em termos de toda uma raça, ou toda a espécie. De tal maneira que gerações sucessivas e raças inteiras acabaram por desenvolver, a partir da sua necessidade de comunicação, um imenso cabedal de capacidades comunicativas. ${ }^{19}$

A finalidade por excelência da linguagem comum, assim como do parco e vago nível de conhecimento que dela deriva nas enunciações sociais, tornou-se a "substituição da pluralidade, a negação do mundo, o niilismo". ${ }^{20} \mathrm{~A}$ comunicação, ainda que possibilite um razoável nível de compreensão interpessoal, elimina as particularidades valorativas e semânticas mais recônditas do discurso individual, ocasionando assim o estabelecimento de práticas comunicativas existencialmente insuficientes, uma vez que elas não partem da afirmação das diferenças intrínsecas dos interlocutores. A linguagem não pode expressar o que é singular e autenticamente único, já que seu elemento próprio é o abstrato, "aquilo que é abstraído de um de outro, o elo que os liga, o centro médio entre eles, aquilo que, por ser comum a ambos, não é mais, estritamente, nem um, nem outro". ${ }^{21}$

Mediante as questões apresentadas, podemos afirmar que o ato de nomear qualquer tipo de coisa consiste então na imposição de uma identidade ao múltiplo, ao móvel, através da supressão das diferenças valorativas, mas esse processo semântico, originado por uma necessidade de supressão das particularidades de cada coisa, cai em esquecimento no decorrer do tempo, de modo que se passa a acreditar na existência de abstrações independentes da mente humana. $O$ homem gregário hipostasia para pretensas dimensões imutáveis as suas próprias criações, originalmente imprecisas e falhas, mas que nem por tais "deficiências" podem ser imputadas como inadequadas ou passíveis de eliminação, pois tal procedimento

\footnotetext{
${ }^{19}$ GIACÓIA JR, Oswaldo. Nietzsche como psicólogo. São Leopoldo: Editora da Unisinos, 2001, p. 34.

${ }^{20}$ MOSÉ, Viviane. Nietzsche e a grande política da linguagem. Rio de Janeiro: Civilização Brasileira, 2005, p. 91.

${ }^{21}$ GIACÓIA JR, Oswaldo. Op. Cit., p. 39.
} 
excludente revelaria o projeto moralista-metafísico de se proclamar a "verdade" acima de tudo, para além do caos, das transformações, do erro e do devir. Silvia Pimenta Rocha, comentando a questão apresentada por Nietzsche, afirma que

\begin{abstract}
Nomear é atribuir identidade a um mundo que só apresenta diferenças. A palavra isola, num mundo em perpétuo devir, determinados grupos de ações, selecionando arbitrariamente algumas características e ignorando outras. ${ }^{22}$
\end{abstract}

Essa redução semântica nasce de uma disposição gregária dos homens que, vivendo em sociedade, necessitam estabelecer relações comunicativas de fácil assimilação, a fim de que a conservação coletiva se viabilize. Se porventura um mesmo objeto possuir diversas denominações, corre-se o risco de gerar uma espécie de "caos semântico", na qual não há entendimento mútuo entre os indivíduos. Conforme argumenta Nietzsche,

Todo conceito surge pela igualação do não-igual. Tão certo como uma folha nunca é totalmente igual a uma outra, é certo ainda que o conceito de folha é formado por meio de uma arbitrária abstração dessas diferenças individuais, por um esquecer-se do diferenciável, despertando então a representação, como se na natureza, além das folhas, houvesse algo que fosse "folha", tal como uma forma primordial de acordo com a qual todas as folhas fossem tecidas, desenhadas, contornadas, coloridas, encrespadas e pintadas, mas por mãos ineptas, de sorte que nenhum exemplar resultasse correto e confiável como cópia autêntica da forma primordial. ${ }^{23}$

Wolfgang Müller-Lauter, esmiuçando essa questão nietzschiana, argumenta que

Essa igualação apoia-se sobre a convicção enganadora de que tudo o que é posto como igual é e permanece idêntico a si mesmo. A igualação é desde sempre um tornar fixo. Na efetividade, não há nada fixo, nada permanente, mas somente a torrente incessante do vir-a-ser e perecer. Esse pensamento fundamental de Nietzsche contrapõe-se completamente ao eleatismo, que está enraizado de modo profundo nas necessidades dos seres vivos. ${ }^{24}$

22 ROCHA, Silvia Pimenta. . Os abismos da suspeita - Nietzsche e o perspectivismo. Rio de Janeiro: Relume Dumará, 2003, p.98.

${ }^{23}$ NIETZSCHE, Friedrich. Sobre Verdade e Mentira no sentido extra-moral, 2007, p.35-36.

${ }^{24}$ MÜLLER-LAUTER, Wolfgang. Op. Cit., p. 42-43. 
Dessa maneira, o processo de eliminação da multiplicidade de denominações para as coisas ocorre progressivamente na esfera social, circunstância que suprime o temor pela ausência de experiências comunicativas compreendidas efetivamente pelos seus membros. O esquecimento nos faz crer que este mundo ordenado e hierarquizado (pela racionalidade humana) não é fruto de uma atividade humana vital, mas é um mundo já dado, um mundo de essências. Argumentando sobre o tema em questão, Viviane Mosé afirma que

A linguagem é produto da necessidade psicológica da exclusão das diferenças, da vontade de nivelamento e redução, do medo da pluralidade e do conflito. Ao invés de uma convenção necessária, capaz de aumentar o poder de atuação do homem no mundo, a palavra se tornou o sinônimo das coisas. Mais do que isso, a crença na correspondência entre as palavras e as coisas terminou por sustentar a vontade de negação da vida, que, ao contrário da convenção dos signos, é mudança, conflito, imprevisibilidade, desconhecimento. ${ }^{25}$

Quanto mais limitado o conjunto de signos partilhados por um grupo social, maior o grau de interação entre os indivíduos constituintes dessa comunidade, ocasionando, todavia, o enfraquecimento das suas capacidades semânticas e das suas disposições simbólicas. Uma vez que é impossível ao ouvinte compreender as particularidades existenciais do discurso pronunciado pelo falante, a comunicação entre ambos circunscreve-se apenas em uma relação semanticamente superficial, onde não ocorre de fato uma experiência de interação, mas uma transmissão vazia de conteúdos que, apesar de dotados de uma razoável compreensão semântica, não favorecem, todavia, o alcance de um autêntico entendimento interpessoal. Segundo Nietzsche,

Já não nos estimamos suficientemente quando nos comunicamos. Nossas verdadeiras vivências não são nada loquazes. Não poderiam comunicar a si próprias, ainda que quisessem. É que lhes faltam as palavras. Aquilo para o qual temos palavras, já o deixamos para trás. Em toda fala há um grão de desprezo. A linguagem, parece, foi inventada apenas para o que é médio, mediano, comunicável. 0

${ }^{25}$ MOSÉ, Op. Cit. p. 19. 
falante já se vulgariza com a linguagem - de uma moral para surdosmudos e outros filósofos. ${ }^{26}$

A comunicação de vivências em sua amplitude mais apurada é impossível, e sempre permanece o caráter inefável do discurso. Talvez o silêncio acerca da experiência da singularidade seja a medida mais adequada a ser tomada pelo pretendente ao discurso, ou então a criação de um mecanismo interativo que permita, ainda que de forma limitada, a tentativa de expressão das vivências de um modo para além da lógica discursiva, sempre redutora. O fator que torna possível haver o diálogo entre os indivíduos, apesar de toda incompatibilidade entre o modo como cada um interpreta singularmente as suas vivências, se dá no estabelecimento de um princípio de analogia entre os comunicadores.

As mais triviais expressões, quando enunciadas pelo falante ao ouvinte, não encontram nesse a repercussão semiológica esperada, pois a vivência que deu origem a tal discurso é inalienável, e as palavras não conseguem descrever a outrem os impulsos primordiais manifestados no falante. Podemos constatar que o citado princípio de analogia é a garantia gnosiológica de haver o estabelecimento de interações dialógicas entre os indivíduos, pois mesmo que um discurso pronunciado para alguém não obtenha neste o mesmo efeito cognitivo despertado no âmago do falante, a possibilidade de se comparar experiências aparentemente comuns suprime esse distanciamento simbólico e interpretativo entre os comunicadores, favorecendo assim o estabelecimento de um razoável nível de consenso, ainda que artificialmente efetivado. Conforme esclarece Scarlett Marton,

Para comunicar, é preciso partir de um solo comum. Não basta ter as mesmas idéias, abraçar as mesmas concepções. Tampouco basta atribuir às palavras o mesmo sentido ou recorrer aos mesmos procedimentos lógicos. É preciso bem mais; é preciso partilhar experiências, comungar vivências. No limite, todo comunicar é tornar comum. Traduzido na consciência e na linguagem, o pensamento já se apresenta sob uma certa perspectiva: a gregária. As idéias, e até as ações de um indivíduo, quando se tornam conscientes e se expressam em palavras, podem vir a perder o que têm de pessoal,

${ }^{26}$ NIETZSCHE, Friedrich. Crepúsculo dos Ídolos ou como se filosofa com o martelo, 2006, p. 77-78. 
singular, único; passando pelo filtro da gregariedade, correm o risco de se tornarem comuns. ${ }^{27}$

O estabelecimento da comunicação interpessoal depende do postulado de que os conceitos enunciados expressam as coisas em si mesmas, e que tais discursos são semanticamente verazes. Esse falseamento da estrutura da linguagem, nessas condições, não passa de uma ilusão cognitiva, de certa maneira favorável ao existir em sociedade, para que se evite a anarquia semântica na comunidade, em favor do estabelecimento da ordem civilizacional, que nasce da adequação da multiplicidade de valores, de condutas e de interpretações a uma esfera normativa que visa criar um estado de univocidade nas relações sociais e em quaisquer tipos de experiências. Entretanto, esse dispositivo demonstra o seu projeto moralista que promove a submissão do singular e original ao âmbito universalista do poder estabelecido, legitimado socialmente através de sua associação com a esfera moralista que envolve o conjunto de valores do indivíduo gregário.

A experiência da vida em sociedade requer, portanto, que cada indivíduo desenvolva em sua consciência a crença na verdade para além da esfera imanente da existência, e que se possa descrever plausivelmente uma suposta realidade ideal. Tal como destaca Nietzsche "acreditamos saber algo acerca das próprias coisas, quando falamos de árvores, cores, neve e flores, mas, com isso, nada possuímos senão metáforas das coisas, não correspondem, em absoluto, às essencialidades originais." 28 Nessas condições, cumpre destacar que o problema maior da práxis comunicacional não reside na impossibilidade da linguagem alcançar uma esfera metafísica ou a "coisa em si", pois tais dimensões suprassensíveis, pensadas a partir de uma compreensão filosófica imanente, não existem. A grande questão se dá especificamente na limitação lingüística de toda palavra. A linguagem seria, portanto, apenas um engenhoso artifício desenvolvido pelo ser humano para possibilitar tanto a facilitação do contato entre os membros das comunidades que interagiam entre si como a dominação do ambiente circundante, da natureza, revelando, no entanto, a sua fraqueza vital e sua inerente

\footnotetext{
${ }^{27}$ MARTON, Scarlett. "Novas liras para novas canções: reflexões sobre a linguagem em Nietzsche". Ide, v.30(44), 2007, p. 37.

${ }^{28}$ NIETZSCHE, Friedrich. Sobre Verdade e Mentira no sentido extra-moral, 2007, p. 33-34.
} 
impossibilidade de viver de modo singular, para além de toda norma gregária. Segundo Luis Henrique de Santiago-Guervós,

A linguagem é também essencialmente metafórica, e pelo mesmo tampouco é capaz de descrever a realidade das coisas em si mesmas. $O$ homem que crê que a linguagem é um meio para o conhecimento da verdade se engana continuamente a si mesmo. ${ }^{29}$

É a dependência humana pelo ideário da verdade no processo comunicativo que gera a crença na existência da estrutura metafísica da linguagem, imputada como objetiva e rigorosa, estabelecendo assim as condições de possibilidade para a criação de pretensos discursos racionais e científicos, que partilham, por conseguinte, de um campo valorativo moralista. Nietzsche enuncia a seguinte questão:

Origem do lógico - De onde surgiu a lógica na mente humana? Certamente do ilógico, cujo domínio deve ter sido enorme no princípio. Mas incontáveis outros seres, que inferiam de maneira diversa da que agora inferimos, desapareceram: e é possível que ela fosse mais verdadeira! Quem, por exemplo, que não soubesse distinguir com bastante freqüência o "igual", no tocante à alimentação, ou aos animais que lhe eram hostis, isto é, quem subsumisse muito lentamente, fosse demasiado cauteloso na subsunção, tinha menos probabilidades de sobrevivência do que aquele que logo descobrisse igualdade em tudo o que era semelhante. Mas a tendência predominante de tratar o que é semelhante como igual - uma tendência ilógica, pois nada é realmente igual - foi o que criou todo fundamento para a lógica. Do mesmo modo, para que surgisse o conceito de substância, que é indispensável para a lógica, embora, no sentido mais rigoroso, nada Ihe corresponda de real - por muito tempo foi preciso que o que há de mais mutável nas coisas não fosse visto nem sentido; os seres que não viam exatamente tinham vantagem exatamente tinham vantagem sobre aqueles que viam tudo "em fluxo" (...) $)^{30}$.

\footnotetext{
29 SANTIAGO-GUERVÓS, Luís Enrique. Arte y Poder: aproximación a la estética de Nietzsche. Madrid: Trotta, 2004, p. 422.

${ }^{30}$ NIETZSCHE, Friedrich. A Gaia Ciência. Trad. de Paulo César de Souza. São Paulo: Companhia das Letras, 2003, p. 110. Como adendo para esta questão apresentada, vejamos os argumentos de Vânia Dutra de Azeredo em Nietzsche e a aurora de uma nova ética, 2008, p. 53: “O signo, enquanto unidade básica de um sistema de significação, funciona como um estabilizador, ou seja, algo que concentra a pluralidade em uma aparente unidade de sentido, donde decorre a possibilidade de determinação de um significado como o significado".
} 
As nossas expressões verbais, derivadas das transposições semânticas das percepções (intrinsecamente parciais e relativas) acerca das coisas com as quais interagimos, acabam por impedir qualquer possibilidade de obtenção de um nível amplo de conhecimento sobre a realidade, eliminando inclusive a crença dogmática de que existe um suprassumo de conhecimento a ser alcançado pela mente humana. É em decorrência dessa questão que Nietzsche enuncia a seguinte sentença: "Perigo da linguagem para a liberdade espiritual - toda palavra é um pré-conceito". ${ }^{31}$ Ao se falar acerca de algo se encerram inúmeras outras possibilidades de expressão semântica sobre essa mesma questão, tornando o discurso tendenciosamente unívoco e, por conseguinte, axiologicamente limitador, desfavorecendo então a ampliação do eixo interpretativo delineado pelo indivíduo em sua vida cotidiana.

O falibilismo e a imprecisão semântica da linguagem impedem, a rigor, o estabelecimento de qualquer possibilidade de se alcançar uma pretensa verdade transcendente sobre aquilo que enunciamos discursivamente, assim como a transmissão plena desses conteúdos informativos, sempre limitados pela carência semântica das palavras. As limitações cognitivas e existenciais do falante são circunstâncias naturais que impedem a obtenção de uma percepção plena dos acontecimentos e da possibilidade de se desvelar intelectualmente a "essência" do mundo, tal como pretendido pela nossa tradição filosófica de raiz metafísica, atrelada imediatamente a parâmetros morais de avaliação. Por mais rigoroso e sistemático que seja, por exemplo, um investigador no processo de formulação do seu discurso, ainda assim ele será epistemologicamente falível. No entanto, compreendendo e aceitando a inevitável limitação semântica de todo discurso, o falante suprime o anseio de descrever de maneira absolutamente veraz as suas vivências e conteúdos informativos, justamente pelo fato de saber que o mecanismo da linguagem é intrinsecamente limitado em suas configurações técnicas. Contudo, o ímpeto de enunciação de pensamentos singulares exige que outras formas de expressão sejam referendadas, tema que abordaremos no tópico a seguir.

\footnotetext{
31 NIETZSCHE, Friedrich. Humano, demasiado humano II - "Opiniões e sentenças diversas" e "O Andarilho e sua sombra". Trad. Paulo César de Souza. São Paulo: Companhia das Letras, 2008, p. 196. 
Possíveis alternativas de superação das limitações semânticas da linguagem gregária

Nesse momento de nossa reflexão cabe problematizarmos a própria questão da expressividade do discurso nietzschiano e sua capacidade de representar a intensidade da filosofia trágica e sua inerente afirmação incondicional da existência. Afinal, se Nietzsche apresenta contínuas objeções ao problema epistemológico da impossibilidade de a linguagem conceitual representar convenientemente as vivências singulares, seus próprios livros publicados não contradiriam tal tese? Nietzsche mesmo alegou ter sofrido desse impasse intelectual em sua grande obra de juventude, $O$ nascimento da Tragédia. Não obstante as profundas intuições filosóficas apresentadas nesse livro e a problematização do espírito dionisíaco em um viés ontológico até então impensável na conservadora tradição acadêmica oitocentista, Nietzsche, na "Tentativa de Autocrítica" (1886) de O nascimento da Tragédia, diz: "Quanto lamento agora que não tivesse então a coragem (ou a imodéstia?) de permitir-me, em todos os sentidos, também uma linguagem própria para intuições e atrevimentos tão próprios". ${ }^{32}$ Nietzsche pondera que as marcantes influências de Schopenhauer e de Wagner na formulação da argumentação da obra confundiram e tornaram "pesada" sua argumentação. Para piorar, a obra foi estigmatizada como desprovida de cientificidade, de rigor filológico, mitigando o prestígio acadêmico de Nietzsche na sua então promissora carreira universitária. Essa situação levou o filósofo alemão a buscar novas formas de expressão das suas ideias de maneira a representar mais convenientemente o teor insólito e intempestivo das mesmas. Nietzsche possuía uma formidável formação artística (composição musical e poética) e tal conhecimento se manifestou no seu estilo de escrita: o uso do aforismo e a assimilação poética na construção discursiva. Não faremos uma análise exaustiva de ambos, pois tal tarefa pode ser apresentada de maneira mais ampla em oportunidade posterior. Porém, ao apresentarmos os fundamentos desses recursos em Nietzsche, conseguiremos compreender as suas alternativas retóricas ao problema da limitação semântica do discurso tradicional.

\footnotetext{
${ }^{32}$ NIETZSCHE, Friedrich. O nascimento da Tragédia ou helenismo e pessimismo. Trad. de Jacó Guinsburg.
} São Paulo: Companhia das Letras, 1992, p. 20. 
O recurso do aforismo, dotado de concisão e precisão argumentativa, encontra na obra de Nietzsche uma poderosa significação filosófica de inovação metodológica, pois se contrapõe ao caráter demonstrativo da argumentação filosófica tradicional e seus parâmetros sistemáticos:

O aforismo, a sentença, nos quais sou o primeiro a ser mestre entre os alemães, são as formas da "eternidade"; minha ambição é dizer em dez frases o que qualquer outro diz em um livro - o que qualquer outro não diz em um livro. ${ }^{33}$

Nietzsche vislumbrou encontrar a justa forma para expressar a embriaguez dionisíaca do pensamento trágico, tal como um ditirambo moderno que fizesse explodir toda ideia de fixidez. Assim falava Zaratustra significa então a culminação da meta filosófica nietzschiana de representar o espírito trágico em palavras, palavras essas que transcendem o formalismo acadêmico e sua inerente frieza expressiva, pois tal obra envolve uma poderosa dimensão poética que concilia belíssimas metáforas, jogos retóricos e mesmo uma musicalidade latente em cada discurso do profeta dionisíaco Zaratustra, que, por princípio de economia, não apresentaremos em sua totalidade, mas apenas um exemplo de sua expressividade:

Não são as palavras e os sons os arco-íris e as pontes fictícias ligando aquilo que está eternamente separado? [...]. Não foram os nomes e os sons dados às coisas, para que o homem se recreasse com elas? É uma linda doidice a fala: graças a ela, o homem dança por cima de todas as coisas. Que aprazíveis são toda a fala e a mentira dos sons! Com os sons, o nosso amor dança sobre arco-íris multicores. ${ }^{34}$

Eis a grande ópera de Nietzsche, na qual o filósofo deu vazão aos seus impulsos criadores mais recônditos, vencendo assim as barreiras comunicacionais usuais da linguagem usual. A potência poética é capaz de quebrar a lógica racional do discurso, e talvez por isso Platão tenha demonstrado tanta aversão aos poetas e suas fabulosas "mentiras", pois suas palavras não representam a pretensa verdade metafísica dos deuses e toda a ordenação transcendente do Mundo das Ideias. Segundo Patrick Wotling,

\footnotetext{
${ }^{33}$ Idem, Crepúsculo dos Ídolos ou como se filosofa com o martelo, 2006, p. 100.

${ }^{34}$ NIETZSCHE, Friedrich. Assim falava Zaratustra - um livro para todos e para ninguém. Trad. de Paulo Osório de Castro. Lisboa: Relógio d'Água, 1998, p.255.
} 
Para construir um pensamento de nuança dotado de uma potência de análise superior àquela do modo tradicional de questionamento metafísico e, ao mesmo tempo, apta a seduzir em favor da vida, Nietzsche se vê, antes de tudo, obrigado a superar as limitações do simples discurso encarregado de exprimir o sentido de um pensamento e, portanto, de elaborar uma forma de expressão radicalmente nova. Essa forma de expressão nova se caracteriza por uma dupla dimensão: ela só pode se constitui pelo movimento mesmo da recusa dos esquemas de expressão e denotação do discurso ordinário, é uma forma imediata que só pode significar afirmando seu distanciamento em relação a esses esquemas. ${ }^{35}$

Conforme a filosofia trágica de Nietzsche, afirmar o discurso poético consiste no reconhecimento de que as palavras semanticamente são inexatas e que nelas não se encontra oculta nenhuma verdade a ser desvelada, mas apenas a tentativa criativa de se representar uma parcela do devir que confunde e suprime toda fixidez identitária, afirmando a vida em sua intensidade plástica: “A arte é mais poderosa do que o conhecimento, pois é ela que quer a vida, e ele alcança apenas, como última meta - o aniquilamento". ${ }^{36}$

\section{Considerações Finais}

A constatação da impossibilidade da linguagem usual representar convenientemente as vivências pessoais do cotidiano não significa a imersão filosófica no niilismo, mas o estímulo para a criação de alternativas discursivas que, apesar das suas inerentes limitações semânticas, não manifestam a pretensão epistêmica de representar de forma veraz a realidade concreta, mas simbolizar a mesma. Daí a importância da criatividade artística manifestada em suas mais diversas vertentes no processo de enunciação do mundo, para além da lógica formalista que, não obstante seu rigor metodológico e seu compromisso com a verdade e com o conhecimento é tecnicamente limitada, frustrando assim a pretensão científica de se converter na linguagem por excelência para explicar a ordem do mundo.

\footnotetext{
${ }^{35}$ WOTLING, Patrick. Op. Cit. p. 48-49.

${ }^{36}$ NIETZSCHE, Friedrich. O nascimento da tragédia ou helenismo e pessimismo, 1996, p. 33.
} 


\section{Referências}

AZEREDO, V. D. Nietzsche e a aurora de uma nova ética. São Paulo: Humanitas/FAPESP, 2008.

BELO, F. Leituras de Aristóteles e de Nietzsche. Lisboa: Calouste Gulbenkian, 1994.

BLONDEL, E. "As Aspas de Nietzsche: Filologia e Genealogia" In: MARTON, Scarlett (org.) Nietzsche Hoje? Trad. de Milton Nascimento. São Paulo: Brasiliense, 1985, p. 110-139.

FINK, E. "Nova experiência de mundo em Nietzsche". In: MARTON, Scarlett (org.) Nietzsche Hoje? Trad. de Sonia Salzstein Goldberg. São Paulo: Brasiliense, 1985, p. 168192.

GIACÓIA JÚNIOR, O. Nietzsche como psicólogo. São Leopoldo: Editora da Unisinos, 2001.

KLOSSOWSKI, P. Nietzsche e o círculo vicioso. Trad. Hortênsia S. Lencastre. Rio de Janeiro: Pazulin, 2000.

KOSSOVITCH, L. Signos e poderes em Nietzsche. São Paulo: Azougue Editorial, 2004. MARTON, S. "Novas liras para novas canções: reflexões sobre a linguagem em Nietzsche". Ide, v.30(44), 2007, p. 32-39.

MOSÉ, V. Nietzsche e a grande política da linguagem. Rio de Janeiro: Civilização Brasileira, 2005.

MÜLLER-LAUTER, W. Nietzsche: sua filosofia dos antagonismos e os antagonismos de sua filosofia. Trad. de Clademir Araldi. São Paulo: Ed. UNIFESP, 2009.

NIETZSCHE, F. Assim falava Zaratustra - um livro para todos e para ninguém. Trad. de Paulo Osório de Castro. Lisboa: Relógio d’Água, 1998.

. Cinco Prefácios para cinco livros não escritos. Trad. de Pedro Süssekind.

Rio de Janeiro: 7Letras, 1996.

. Crepúsculo dos Ídolos ou como se filosofa com o martelo. Trad. de Paulo César de Souza. Companhia das Letras: São Paulo: 2006.

A Gaia Ciência. Trad. de Paulo César de Souza. São Paulo: Companhia das Letras, 2003.

Genealogia da Moral - Uma polêmica. Trad. de Paulo César de Souza. São Paulo: Companhia das Letras, 2000. 
. Humano, demasiado humano II - "Opiniões e sentenças diversas" e "O Andarilho e sua sombra". Trad. Paulo César de Souza. São Paulo: Companhia das Letras, 2008.

O nascimento da Tragédia ou helenismo e pessimismo. Trad. de J. Guinsburg. São Paulo: Companhia das Letras, 1992.

. Da Retórica. Trad. de Tito Cunha. Lisboa: Vega, 1999.

. Sobre verdade e mentira no sentido extra-moral, Trad. de Fernando de Moraes Barros. São Paulo: Hedra, 2007.

PLATÃO. Crátilo. Trad. de Maria José Figueiredo. Lisboa: Instituto Piaget, 2001.

ROCHA, S. P. V. Os abismos da suspeita - Nietzsche e o perspectivismo. Rio de Janeiro: Relume Dumará, 2003.

SANTIAGO-GUERVÓS, L. E. Arte y Poder: aproximación a la estética de Nietzsche. Madrid: Trotta, 2004.

SUAREZ, R. Nietzsche e a linguagem. Rio de Janeiro: 7Letras, 2011.

WOTLING, P. Nietzsche e o problema da civilização. Trad. de Vinicius de Andrade. São Paulo: Barcarolla, 2013. 